\title{
PENGARUH MODEL PEMBELAJARAN BERBASIS \\ MASALAH TERHADAP HASIL BELAJAR FISIKA SISWA PADA MATERI POKOK LISTRIK DINAMIS DI SMA N 1 KISARAN
}

\author{
Hani Diana Sipayung *) dan Eidi Sihombing **) \\ *) Mahasiswa Program Studi Pendidikan Fisika Unimed \\ **) Dosen Jurusan Fisika Unimed \\ hani_diana@rocketmail.com ; eidifisika@gmail.com
}

\begin{abstract}
Abstrak
Tujuan penelitian ini untuk mengetahui pengaruh model pembelajaran berdasarkan masalah terhadap hasil belajar fisika mengenai listrik dinamis di SMA Negeri 1 Kisaran. Penelitian quasi eksperimen ini mempunyai populasi seluruh siswa kelas $\mathrm{X}$ Negeri 1 Kisaran sebanyak sepuluh kelas dengan mengambil sampel dua kelas dengan cara simple random sampling. Instrumen yang digunakan untuk mengetahui hasil belajar siswa adalah tes hasil belajar dalam bentuk essay tes dengan jumlah delapan soal. Hasil kemampuan siswa untuk kedua kelas sebelum perlakuan diberikan menunjukkan kemampuan yang relatif sama. Hasil kemampuan setelah perlakuan menunjukkan bahwa kemampuan kelas eksperimen yang menggunakan pembelajaran berbasis masalah lebih tinggi dibanding siswa yang berada di kelas kontrol dengan pembelajaran konvensional dinyatakan setelah analisis data menunjukkan uji-t dimana $t_{\text {hitung }}$ $>t_{\text {tabel }}(2,47>2,39)$ pada taraf signifikansi $\alpha=0,05$.
\end{abstract}

Kata Kunci: model pembelajaran berbasis masalah, hasil belajar fisika.

\begin{abstract}
This research aimed to know the effect of learning model based on problem to physics result about Dynamic electricity in SMA N 1 Kisaran. This quasi experiment research consist of senior high school student class X SMA N 1 Kisaran as many as classes with take two classes with sample random sampling design. Instrument used to know student learning outcomes is achievement test in the form of essay test with eight question. The result of the ability of students to class president before treatment is given show relatively similiar capabilities. The result of ability after treatment showed that the experimental class capability that uses problem-based on learning is higher than students who are in class control with conventional study revealed after the analysis of the data showed t-test where $t_{\text {arithmetic }}>\mathrm{t}_{\text {table }}(2.47>2.39)$ at significance level $\alpha=0,05$.
\end{abstract}

Keywords: problem-based learning model, physics learning outcomes. 


\section{Pendahuluan}

Kualitas pendidikan selalu dapat dipersaingkan dan salah satu masalah yang dihadapi dalam pendidikan di Indonesia. Proses pembelajaran siswa di kelas lebih di arahkan pada siswa yang kreatif dan inovatif dalam mengelola kemampuannya, hal ini dijelaskan oleh Tasoglu dan Bacak (2014),..." "This is because conceptual physics it is not enough that a student can only identify and memorize the concepts in order to understand concepts and the relationship between these concepts. Instead of this proper learning environments should be created for students where they can study and invent their scientific knowledge as scientists. Thus the student, without the need to memorize knowledge, will gain the ability to Conceptualize learning".

Keberhasilan proses pembelajaran dapat dilihat dari hasil belajar siswa yang merupakan produk yang dapat di ukur dari kegiatan pembelajaran.

Fisika salah satu cabang ilmu pengetahuan alam merupakan pelajaran yang tidak efektif jika hanya dipelajari secara teori dan matematisnya saja, tetapi juga harus ditekankan pada penguasaan konsep dan aplikasinya dalam kehidupan sehari-hari, sehingga siswa mampu menyelesaikan masalah yang berhubungan dengan fisika yang terjadi di sekitarnya (Borhan, M, T., 2011).

Hasil observasi awal di sekolah SMA Negeri 1 Kisaran memberikan kesimpulan bahwa kegiatan pembelajaran yang diterapkan dikelas masih cenderung berpusat pada guru (teachercentered), sehingga siswa menjadi pasif dan belum dapat menciptakan pembelajaran yang berpusat kepada siswa (Student-Centered) dimana guru hanya berperan sebagai fasilitator. Permasalahan tersebut menyebabkan hasil belajar siswa kelas sepuluh masih tergolong rendah yang dinyatakan dari nilai ujian tengah semester.

$$
\text { Upaya mengatasi }
$$

permasalahan di atas adalah mengembangkan model pembelajaran yang efektif, menarik perhatian siswa, membangkitkan motivasi siswa, melibatkan siswa secara aktif, dan memperhatikan kemampuan siswa. Alternatif yang dapat digunakan untuk mengatasi kesulitan tersebut di atas adalah menciptakan suasana pembelajaran yang langsung berhubungan dengan kehidupan sehari-hari yaitu model pembelajaran berdasarkan masalah. Model pembelajaran berdasarkan masalah adalah proses pembelajaran siswa pada masalah autentik sehingga siswa dapat menyusun pengetahuannya sendiri, menumbuhkembangkan

keterampilan yang lebih tinggi dan inquiry, memandirikan siswa dan meningkatkan kepercayaan diri sendiri (Hosnan, 2014:295; Wynn, at all, 2014; Temel,S., 2014). Model pembelajaran ini dirancang dengan tujuan untuk membantu siswa mengembangkan kemampuan berfikir dan mengembangkan kemampuan dalam memecahkan masalah kehidupan sehari-hari sehingga siswa lebih paham terhadap konsep fisika yang berkaitan dengan kehidupan seharihari (Seham, A dan Samah, A., 2015).

Pemaparan tentang penelitian sebelumnya yang berkaitan dengan pembelajaran berbasis masalah diantaranya: hasil penelitian Ozansoy (2014) bahwa Problem- 
Based Learning (PBL) diminati di negara berkembang seperti Malaysia. Selcuk, at all., (2013) mengatakan PBL dalam pembelajaran fisika lebih baik bila dibanding dengan model tradisional. Penelitian oleh Nordin dan Selvan (2013), mengungkapkan penelitian tentang pengaplikasian model PBL sebagai pembelajaran yang inovatif untuk meningkatkan kualitas pendidikan dan kompetensi lulusan di abad. Selanjutnya adalah (Khairuddin, 2012) di SMA N 1 Ngaglik diperoleh nilai pretest di kelas eksperimen adalah 48,11 dan nilai rata-rata postest adalah 66,06 sehingga dinyatakan bahwa terdapat pengaruh Penerapan Model Problem Based Learning terhadap peningkatan hasil belajar fisika kelas X untuk materi listrik dinamis dengan hasil yang cukup signifikan.

Hasil penelitian di atas menunjukkan ada pengaruh yang signifikan antara model pembelajaran berdasarkan masalah terhadap hasil belajar siswa. Pembelajaran berdasarkan masalah mengorientasikan siswa kepada masalah multidisiplin, menuntut kerjasama, dan menghasilkan karya.

Kegiatan pembelajaran yang di tawarkan adalah: a) memberikan masalah-masalah yang bersifat nyata kepada siswa, b) menjelaskan materi, c) melaksanakan pembelajaran dengan pendekatan saintifik, d) membagi siswa dalam kelompok yang terdiri dari 7 orang siswa, e) mengarahkan siswa membuat hipotesis, f) melakukan tanya jawab kepada siswa g) membimbing siswa untuk membuktikan hipotesis siswa melalui percobaan dengan memberikan LKS, h) membimbing siswa membuat kesimpulan.

Tujuan penelitian ini untuk mengetahui hasil belajar siswa dengan model pembelajaran berbasis masalah dan model pembelajaran konvensional, mengetahui aktivitas proses pembelajaran dengan menggunakan model pembelajaran berbasis masalah dan pembelajaran konvensional, mengetahui pengaruh model pembelajaran berbasis masalah terhadap hasil belajar siswa.

Model pembelajaran berdasarkan masalah adalah proses pembelajaran siswa pada masalah autentik sehingga siswa dapat menyusun pengetahuannya sendiri, menumbuhkembangkan

keterampilan yang lebih tinggi dan inquiry, memandirikan siswa dan meningkatkan kepercayaan diri sendiri (Hosnan, 2014:295; Eldy, at all., 2013; Tasoglu, at all., 2014). Pembelajaran Berdasarkan Masalah (Problem Based Learning), merupakan suatu proses atau upaya untuk mendapatkan suatu penyelesaian tugas atau situasi yang benar-benar nyata sebagai masalah dengan menggunakan aturan-aturan yang sudah diketahui (Shaer, A, E dan Gaber,H., 2011). Model pembelajaran berdasarkan masalah terdapat lima tahap utama yang dimulai dengan memperkenalkan siswa tehadap masalah, melakukan penyelidikan, dan diakhiri dengan tahap penyajian dan analisis hasil kerja siswa yang kemudian di evaluasi oleh guru. Kelima tahapan tersebut disajikan dalam bentuk tabel dalam (Trianto, 2009:98). 
Tabel 1.Sintaks Model

Pembelajaran Berdasarkan Masalah

\begin{tabular}{|c|c|}
\hline Indikator & $\begin{array}{l}\text { Aktifitas / Kegiatan } \\
\text { Guru }\end{array}$ \\
\hline $\begin{array}{l}\text { Orientasi siswa } \\
\text { kepada masalah }\end{array}$ & $\begin{array}{l}\text { Guru menjelaskan } \\
\text { tujuan pembelajaran, } \\
\text { menjelaskan logistik } \\
\text { yang dibutuhkan, } \\
\text { mengajukan fenomena } \\
\text { atau demonstrasi atau } \\
\text { cerita untuk } \\
\text { memunculkan masalah, } \\
\text { memotivasi siswa } \\
\text { untuk terlibat dalam } \\
\text { aktivitas pemecahan } \\
\text { masalah yang dipilih. }\end{array}$ \\
\hline $\begin{array}{c}\text { Mengorganisasi } \\
\text { kan siswa untuk } \\
\text { belajar }\end{array}$ & $\begin{array}{l}\text { Guru membantu siswa } \\
\text { mendefenisikan dan } \\
\text { mengorganisasikan } \\
\text { tugas belajar yang } \\
\text { berhubungan dengan } \\
\text { masalah tersebut. }\end{array}$ \\
\hline $\begin{array}{l}\text { Membimbing } \\
\text { penyelidikan } \\
\text { individual } \\
\text { maupun } \\
\text { kelompok }\end{array}$ & $\begin{array}{l}\text { Guru mendorong siswa } \\
\text { untuk mengumpulkan } \\
\text { informasi yang sesuai, } \\
\text { melaksanakan } \\
\text { eksperimen, untuk } \\
\text { mendapatkan } \\
\text { penjelasan pemecahan } \\
\text { masalah. }\end{array}$ \\
\hline $\begin{array}{c}\text { Mengembangka } \\
\text { n dan } \\
\text { menyajikan } \\
\text { hasil karya }\end{array}$ & $\begin{array}{l}\text { Guru membantu siswa } \\
\text { dalam merencanakan } \\
\text { dan menyiapkan karya } \\
\text { yang sesuai seperti } \\
\text { laporan, video, model } \\
\text { dan membantu mereka } \\
\text { untuk berbagai tugas } \\
\text { dengan temannya. }\end{array}$ \\
\hline $\begin{array}{l}\text { Menganalisis } \\
\text { dan } \\
\text { mengevaluasi } \\
\text { proses } \\
\text { pemecahan } \\
\text { masalah } \\
\end{array}$ & \begin{tabular}{lr}
\multicolumn{3}{l}{ Guru membantu siswa } \\
melakukan refleksi \\
atau evaluasi & terhadap \\
penyelidikan mereka \\
dalam proses-proses \\
yang mereka gunakan.
\end{tabular} \\
\hline
\end{tabular}

\section{Metode Penelitian}

Penelitian ini adalah kuasi eksperimen dengan populasi seluruh siswa kelas X SMAN 1 Kisaran dan sampel ditentukan dengan cara teknik kelas acak (cluster random sampling) sebanyak 2 kelas, yaitu: satu kelas dijadikan kelas eksperimen dengan menggunakan model pembelajaran berbasis masalah dan kelas lainya dijadikan kelas kontrol dengan menggunakan model pembelajaan konvensional. Desain penelitian ini dapat dilihat pada tabel berikut ini:

Tabel 2. Two Group Pretest-Posttest Design

\begin{tabular}{cccc}
\hline Kelas & Pretest & Perlakuan & Postest \\
\hline Eksperimen & $\mathrm{T}_{1}$ & $\mathrm{X}_{1}$ & $\mathrm{~T}_{2}$ \\
\hline Kontrol & $\mathrm{T}_{1}$ & $\mathrm{X}_{2}$ & $\mathrm{~T}_{2}$ \\
\hline
\end{tabular}

Keterangan :

$\mathrm{X}_{1}$ : pembelajaran menggunakan model pembelajaran berbasis masalah

$\mathrm{X}_{2}$ : pembelajaran menggunakan model pembelajaran konvensional $\mathrm{T}_{1}$ : Pretest diberikan kepada kelas eksperimen dan kelas kontrol sebelum perlakuan.

$\mathrm{T}_{2}$ : Postest diberikan setelah perlakuan pada kelas eksperimen dan kelas kontrol.

Data-data yang diperoleh terlebih dahulu dianalisis dengan uji hipotesis, setelah terlebih dahulu diuji normalitas dan uji homogenitas data.

Uji normalitas diadakan untuk mengetahui normal tidaknya data penelitian tiap variabel penelitian, uji yang dipakai adalah uji Lilliefors, kemudian uji homogenitas untuk mengetahui kedua sampel berasal dari populasi yang homogen, dengan menggunakan persamaan:

$$
F_{\text {hitung }}=\frac{\text { varians terbesar }}{\text { varians terkecil }}=\frac{s_{1}^{2}}{s_{2}^{2}}
$$

Pengujian hipotesis dilakukan dengan uji $t$ dua pihak uji kesamaan rata-rata pretest dan uji t satu pihak (uji kesamaan rata-rata postes). Uji t 
dua pihak digunakan untuk mengetahui kesamaan kemampuan awal siswa pada kedua kelompok sampel. Hipotesis yang diuji berbentuk :

$\mathrm{H}_{0}: \mu_{1}=\mu_{2}$ kelas eksperimen dan kelas kontrol mempunyai kemampuan awal sama.

$\mathrm{H}_{\mathrm{a}}: \mu_{1} \neq \mu_{2}$ kelas eksperimen dan kelas kontrol mempunyai kemempuan awal berbeda.

Data penelitian yang telah berdistribusi normal dan homogen akan diuji hipotesis menggunakan uji- t (Sudjana, 2005), yaitu :

$$
\mathrm{t}=\frac{\bar{X}_{1}-\bar{X}_{2}}{S \sqrt{\frac{1}{n_{1}}+\frac{1}{n_{2}}}}
$$

dimana $S$ adalah varians gabungan yang dihitung dengan rumus :

$$
S^{2}=\frac{\left(n_{1}-1\right) S_{1}^{2}+\left(n_{2}-1\right) S_{2}^{2}}{n_{1}+n_{2}-2}
$$

Kriteria pengujian adalah : terima $\mathrm{Ho}_{\mathrm{O}}$ jika $-t_{1-1 / 2} \alpha<t<t_{1-1 / 2} \alpha$ dimana $t_{1-1 / 2} \alpha$ didapat dari daftar distribusi $t$ dengan $\mathrm{dk}=\left(\mathrm{n}_{1}+\mathrm{n}_{2}-2\right)$ dan $\alpha=0,01$. Untuk harga t lainnya $\mathrm{H}_{\mathrm{O}}$ ditolak.

Uji t satu pihak digunakan untuk mengetahui pengaruh dari suatu perlakuan yaitu model pembelajaran berdasarkan masalah terhadap hasil belajar siswa. Hipotesis yang diuji berbentuk :

$$
\begin{aligned}
& \mathrm{H}_{0}: \mu_{1} \leq \mu_{2} \\
& \mathrm{H}_{\mathrm{a}}: \mu_{1}>\mu_{2}
\end{aligned}
$$

keterangan :

$\mu_{1} \leq \mu_{2}$ : Hasil belajar siswa pada kelas eksperimen lebih kecil atau sama dengan kelas kontrol, berarti tidak ada pengaruh model pembelajaran berdasarkan masalah terhadap hasil belajar siswa.

Analisis korelasi digunakan untuk mengetahui bagaimana hubungan aktivitas dan hasil belajar siswa pada penerapan model pembelajaran berbasis masalah terhadap hasil belajar siswa digunakan persamaan korelasi product moment antara lain adalah :

Tabel 3. Pedoman Pemberian Interpretasi Koefisien Korelasi

\begin{tabular}{ll}
\hline $\begin{array}{c}\text { Interval } \\
\text { Koefisien }\end{array}$ & \multicolumn{1}{c}{$\begin{array}{c}\text { Tingkat } \\
\text { Hubungan }\end{array}$} \\
\hline $0,00-0,199$ & Sangat rendah \\
$0,20-0,399$ & Rendah \\
$0,40-0,599$ & Sedang \\
$0,60-0,799$ & Kuat \\
$0,80-1,000$ & Sangat kuat \\
\hline Arikunto,S. & (2013:245). Prosedur \\
Penelitian &
\end{tabular}

\section{Hasil dan Pembahasan}

Hasil penelitian, sebelum diberikan pembelajaran kepada kedua kelompok sampel diperoleh rata-rata pretes siswa kelas eksperimen sebesar 24,93 dan kelas kontrol sebesar 25,50. Pembelajaran pada kelas eksperimen dan kelas kontrol diberikan dengan dua perlakuan yang berbeda, pada kelas eksperimen diberi pembelajaran dengan model pembelajaran berdasarkan masalah dan kelas kontrol dengan model pembelajaran konvensional maka diperoleh ratarata postes untuk kelas eksperimen sebesar 66,00 dan kelas kontrol 57,04 .

Kelas eksperimen dengan menggunakan model pembelajaran berdasarkan masalah dan kelas kontrol menggunakan model pembelajaran konvensional, diperoleh perhitungan uji hipotesis sebagai berikut : $t_{\text {hitung }}>t_{\text {tabel }}=2,59$ 
$>$ 2,39, maka Ho ditolak dan $\mathrm{H}_{\mathrm{a}}$ diterima atau dengan kata lain ada pengaruh model pembelajaran berdasarkan masalah dalam meningkatkan hasil belajar siswa.

Peningkatan hasil belajar menggunakan model pembelajaran berdasarkan masalah lebih baik dikarenakan model pembelajaran ini memiliki beberapa kelebihan yaitu : 1) siswa belajar untuk memperoleh pengetahuan dan melatih kemampuan intelektual siswa, 2) merangsang keingintahuan dan memotivasi kemampuan siswa, 3) siswa didorong untuk belajar sendiri, belajar aktif melalui konsepkonsep, prinsip-prinsip, 4) mengajarkan siswa untuk memahami isi dan proses dalam waktu yang bersamaan, 5) siswa belajar menyelesaikan masalah, mengevaluasi solusi, dan berfikir logis, hal ini dapat dilihat pada saat siswa bekerja bersama kelompok mengemukakan hipotesis dan pada saat siswa bertanya kepada guru serta pada saat siswa mengemukakan pendapat atau mengemukakan apa yang telah siswa dapat dalam proses pembelajaran tersebut, 6) siswa juga dituntut belajar sambil berbuat sehingga siswa lebih mengingat apa yang telah siswa pelajari. Pernyataan ini didukung oleh penelitian yang dilakukan oleh Eldy dan fauziah, (2013) yang memperoleh kesimpulan dari hasil penelitiannya bahwa problem based learning mempengaruhi berfikir kritis dan berfikir kreatif-kritis terhadap mahasiswa fisika universitas sabah malaysia.

Kelemahan yang menyebabkan pencapaian hasil belajar belum maksimal dan peningkatan hasil belajar masih tergolong rendah, kelemahan tersebut antara lain, 1) siswa yang memilih duduk diam dan menunggu hasil yang diperoleh oleh temannya daripada bergabung membantu temannya untuk memperoleh data tersebut, 2) keterbatasan peneliti dalam mengalokasikan waktu pada saat siswa mengajukan hasil diskusi sehingga tidak semua kelompok dapat menyajikan hasil diskusi kelompoknya, 3) siswa masih kurang memiliki kemauan sendiri untuk mempelajari sendiri materi listrik dinamis sehingga dalam penelitian ini penerapan model pembelajaran berbasis masalah kurang mencapai karakteristik model pembelajaran berbasis masalah yang seharusnya.

Model pembelajaran berdasarkan masalah dapat dilakukan seefektif mungkin jika sampel penelitian merupakan siswasiswi yang memiliki pemahaman yang cukup untuk materi yang diajarkan, jumlah siswa dalam satu kelas tidak terlalu banyak dan mahasiswa calon guru memiliki kemampuan pengelolaan kelas yang baik maka model pembelajaran berdasarkan masalah dapat dijadikan salah satu model pembelajaran yang dapat meningkatkan hasil belajar siswa untuk materi fisika.

Hasil observasi keseluruhan yang dilakukan terhadap aktivitas siswa pada pertemuan I sampai pertemuan III antara kelas kontrol dan kelas eksperimen menunjukkan hasil yang sangat berbeda, hal ini menunjukkan adanya peningkatan aktivitas siswa menjadi lebih baik di kelas eksperimen karena model pembelajaran berdasarkan masalah mengarahkan siswa untuk lebih aktif, kreatif dalam melakukan kegiatan pembelajaran yang disertai 
praktikum dan berfikir kritis sehingga siswa lebih termotivasi untuk memahami materi yang disampaikan.

Meningkatnya aktivitas belajar siswa di kelas eksperimen ternyata memiliki hubungan yang sangat rendah dalam mempengaruhi peningkatan hasil belajar siswa. Hasil belajar siswa yang diajarkan dengan menggunakan model pembelajaran berdasarkan masalah diperoleh lebih tinggi dibandingkan dengan hasil belajar siswa dengan model konvensional, sama halnya dengan penilaian aktivitas belajar siswa. Penilaian aktivitas di kelas eksperimen adalah 73,52 dan di kelas kontrol rata-rata penilaian aktivitas belajar siswa adalah 54,4.

Kategori soal untuk mengetahui hasil belajar siswa merupakan kategori soal C4, C5, dan C6 sesuai dengan revisi taksonomi bloom. kelas kontrol lebih unggul untuk kategori soal C4, hal ini disebabkan di kelas kontrol penjelasan tentang soal soal analisis lebih cepat dipahami siswa karena dijelaskan dengan metode ceramah, tetapi sangat rendah untuk kategori soal C5 dan C6. Pada kelas eksperimen lebih unggul untuk kategori soal C5 dan C6, hal ini disebabkan soal-soal C5 dan C6 mengacu kepada kerja nyata pada saat praktikum dilakukan untuk menyelesaikan masalah yang diberikan, siswa pada kelas eksperimen menjadi lebih memahami cara menyelesaikan kategori soal C5 dan C6.

\section{Kesimpulan}

Kesimpulan bahwa

kemampuan hasil belajar dan aktivitas belajar menggunakan PBL lebih baik bila dibanding dengan menggunakan metoda konvensional. Penggunaan waktu dalam pembelajaran harus diperhatikan dengan baik.

\section{Daftar pustaka}

Arikunto, S. (2013). Dasar-Dasar Evaluasi Pendidikan Edisi Revisi. Penerbit Bumi Aksara, Jakarta.

Arikunto, S. (2002). Prosedur Penelitian. Penerbut Rineka Cipta, Jakarta.

Borhan, M, T. (2012). Problem Based Learning (PBL) in Malaysian Higher Education A Review of Research on Learners Experience and Issues of Implementations. ASEAN Journal of Engineering Education. 1. 1. (pp: 48)

Eldy, E, F., Fauziah, S. (2013). Integrated PBL Approach Preliminary findings to wards Physics Student's Critical Thinking and Creative - Critical Thinking. Jurnal dari International Journal of Humanities and Social Science Invention Vol. 2. 3. (pp: 18)

Hosnan. (2014). Pendekatan sainstifik dan Kontekstual dalam Pembelajaran Abad 21. Penerbit Elexmedia Komputindo, Jakarta.

Khairuddin. (2012). Pengaruh Model Problem Based Learning (Belajar Berdasarkan Masalah) Terhadap Hasil Belajar 
Kognitif Siswa SMA $N \quad 1$ Ngaglik Pada Pembelajaran Fisika Untuk Materi Listrik Dinamis. Diakses (http://journal.student.uny.ac.id/ jurnal/artikel/280/46/80). Vol. 1. Sabtu, 17 Januari 2015, pukul : 20.00)

Nordin, N, M., Tamil, S, S.(2013). .Problem Based Learning Approach in the Designing of E Content for Engineering Courses. Jurnal dari Canadian Center of Science and Education . 9.(pp: 300)

Ozansoy, C. (2014). The Application of PBL Approach for Teaching the First Year of an Electrical and Electronics engineering Course. Diakses (http://www.westpoint.edu/cf e/literature/hitt-10.pdf).

Sabtu, 08 Agustus 2015, pukul : 10.30)

Seham, A ., Samah, A. (2015). Effect of Problem-Based Learning Strategy on Development of Problem Solving Skills Among Undergraduate Nursing Student. IOSR-JNHS. 4. 3.(pp: 02)

Selcuk, G, S., Serap, C., Mehmet,S. (2013). A Comparison of Achievement in ProblemBased, Strategic and Tradisional Learning Classes in Physics. Jurnal dari IJONTE . 4 . 1.(pp: 154)

Shaer, A, E., Gaber, H. (2014). Impact of Problem-Based
Learning on Student's Critical Thinking Dispositions, Knowledge, Acquisition and Retention. Journal of Education and Practice. 5. (pp:74)

Sudjana, N. (2005). Metoda Statistika. Tarsito, Bandung.

Tasoglu, A, K., Bakac, M. (2014). The Effect of Problem Based Learning Approach on Conceptual Understanding in Teaching of Magnetism Topics. Jurnal dari Eurasian Journal of Physics and Chemistry Education . 6. 2. (pp: 110)

Temel, S. (2014). The Effects of Problem Based Learning on Pre-Service Teachers Critical Thinking Dispositions and Perceptions of Problem Solving ability. South African Journal of Education. 34. 1. (pp: 02)

Trianto. (2009). Mendesain Model Pembelajaran InovatifProgresif. Penerbit Kencana Prenada Media Group, Jakarta

Wynn, C, T., Richard, S, M., Carolee, A, L. (2014). Measuring the Effects of Problem-Based Learning on the Development of Postformal Thinking skills and Engagement of First Year Learning Community Students. Jurnal dari Learning Community Research and Practice. 2. 2. (pp:01) 
